\title{
Comparison of Heavy Metals Contents for Some Cigarettes Brands
}

\author{
${ }^{1}$ Lucien Agbandji, ${ }^{2}$ Edorh A. Patrick, ${ }^{3}$ Georges B. Gbago, ${ }^{4}$ Luc Koumolou, \\ ${ }^{5}$ Sosthene Adisso, ${ }^{4}$ Patient Guedenon, ${ }^{1}$ Soulemane Ahodjide, ${ }^{6}$ Brice Sinsin and ${ }^{1}$ Michel Boko
}

\author{
${ }^{1}$ Multidisciplinary Doctoral School (EDP), Faculty of Letters, Arts and Humanities (FLASH), \\ University of Abomey-Calavi (UAC), 01 BP 526, Cotonou, Benin \\ ${ }^{2}$ Department of Biochemistry and Cell Biology, Faculty of Science and Technology (FAST), \\ University of Abomey, 03 BP 1463 Jericho Cotonou, Benin \\ ${ }^{3}$ Faculty of Law and Political Science (FADESP), \\ University of Abomey-Calavi (UAC), 01 BP 526, Cotonou, Benin \\ ${ }^{4}$ Laboratory of Toxicology and Environmental Health, \\ Interfaculty Centre for Training and Research Environment for Sustainable Development, \\ University of Abomey-Calavi, 03 BP 1463 Jericho Cotonou, Benin \\ ${ }^{5}$ University Center of Gynecology and Obstetrics (CUGO), Faculty of Health Sciences (FSS), \\ University of Abomey-Calavi (UAC), 01 BP 526, Cotonou, Benin \\ ${ }^{6}$ Faculty of Agronomy, University of Abomey-Calavi, 03 BP 1463 Jericho Cotonou, Benin
}

Received 2012-05-30, Revised 2013-01-02; Accepted 2013-02-21

\begin{abstract}
According certain studies, smoking could be associated with an increase of health risk link to heavy metals and these risks would be more important in developed countries. So, this study attempted to verify these informations throuth the comparison of the levels of lead $(\mathrm{Pb})$, cadmium $(\mathrm{Cd})$ nickel $(\mathrm{Ni})$ and arsenic ( $\mathrm{As})$ in some cigarettes sold in Benin and France. Composite samples of cigarette brands purchased in Benin (developing country) and France have been taken in the same periods from the two countries. Samples were analyzed for cadmium $(\mathrm{Cd})$, lead $(\mathrm{Pb})$, nickel $(\mathrm{Ni})$ and arsenic (As) by atomic absorption spectrophotometer. The amounts (average \pm SD) have been compared by the statistical Student $p$ test $(T>t)$ $=0.05$. The results showed that all the cigarettes tobacco is differently contaminated with $\mathrm{Cd}, \mathrm{Pb}, \mathrm{Ni}$ and As. The amounts reveal that for all metals the regulatory limits are over passed but the level of contamination varies from one brand to another one. However, it could not be obvious to conclude that the cigarettes in developed countries are more concentrated in heavy metals than those of developing countries. This affirmation has been discussed. Indeed, it appeared that the level of lead and arsenic obtained in some cigarette brands purchased in Benin were significantly higher than $(\mathrm{p}<0.05)$ those sold in France. Otherwise, all the France cigarette brands contain about two or three times more cadmium that Beninese cigarettes. However, excepted these particularities, there was no significant differences $(p<0.05)$ between heavy metals contents in cigarette brands sold in Benin and France. Overall, findings from this study suggest that, Beninese cigarettes did not differ in heavy metals contents from cigarettes sold in France markets. The high levels of toxic metals recorded in some cigarette tobacco from each country are probably the result of soil conditions where tobacco is grown. But, the presence of high levels of heavy metals may constitute a global health concern. The adoption of reasonable behavior are needed to preserve the public health.
\end{abstract}

Keywords: Cigarette Brands, Developed Country, Developping Country, Toxic Metals, Health Risk

Corresponding Author: Lucien Agbandji, Multidisciplinary Doctoral School (EDP), Faculty of Letters,

Arts and Humanities (FLASH), University of Abomey-Calavi (UAC), 01 BP 526, Cotonou, Benin 


\section{INTRODUCTION}

Under the label of progress, globalization and civilization, the cigarette from the West (Connolly et al., 1986; Galanti et al., 1997), was introduced and widespread in Africa (Kaplan et al., 1990; Peltzer, 2003) and even in Benin, despite the legislative, regulatory, ethical and health barriers (Sasco et al., 2004). Tobacco is a fast-growing plant (Saad et al., 2006) and, like all the natural plants, it uptake toxic metals from the soil (Pietel et al., 2000). Some of these contaminants can be naturally found in soils where tobacco plants are grown (Xian, 1989), others were brought in soils through fertilizer and various pesticides during the cultivation of tobacco crops (Deluisa et al., 1996; Bourrelier and Berthelin, 1998). Besides, smoking is associated with an increase in heavy metals in human tissues (Friberg, 1974; Kjellstrom, 1979; Scherer and Barkemeyer, 1983; Mussalo-Rauhamaa et al., 1986) and these health risks are more importants in developed countries (Watanabe et al., 1987). In order to confront these informations, this study attempted to determine and compare the concentrations of toxic metals (lead, cadmium, nickel and arsenic) in some cigarette brands purchased in Benin, developping country and in France.

\section{MATERIALS AND METHODS}

\subsection{Processing and Analysis}

6 brands of cigarette had been taken from some locations in Benin between march and april 2009 and 3 brands of cigarettes were purchased in France. There are:

- From Benin:

- Yes, Green Concorde and Red Concorde that were manufactured by BATCo Company in Benin

- Rothmans King Size, Craven A and Marlboro that were imported but smoked in Benin

- From France:

- Rothmans King Size, Craven A and Marlboro

All the samples have undergone the necessary treatment before heavy metals analysis by electrothermal atomic absorption spectrophotometer according to the method described in (Anane et al., 1995; Vaidya and Rantala, 1996). For each sample, there were 3 replicates and the average values and standard deviation were calculated.

\subsection{Statistical Tests}

Results are presented in tables as average \pm standard deviation and analyzed using SPSS 16.0 software. All statistical treatments performed in this study show many comparisons. This procedure involves comparing pair-wise all or part of the results using Student $p$ test $(T>t)=0.05$.

\section{RESULTS}

The results are summarized in Table 1-3.

- Table 1: Concentration $(\mu \mathrm{g} / \mathrm{g})$ of heavy metals in imported cigarettes and cigarettes made and sold in Benin

- Table 2: Concentration $(\mu \mathrm{g} / \mathrm{g})$ of heavy metals in cigarettes made and sold in France

- Table 3: Comparison of concentrations $(\mu \mathrm{g} / \mathrm{g})$ of heavy metals in cigarettes sold in Benin and France

\section{DISCUSSION}

The results show that all the cigarette samples taken from the two countries are contaminated with lead $(\mathrm{Pb})$, Cadmium (Cd), Nickel (Ni) and Arsenic (As). As depicted in Table 1-3, the levels of metals of health varied considerably among brands. The amounts reveal that, for all metals, the regulatory limits $\left(1 \mu \mathrm{g} \mathrm{g}^{-1}\right)$ are over passed but the level of contamination varies from one cigarette brand to another one.

\subsection{Metals Concentration in Beninese Cigarettes}

The average concentrations of heavy metals in cigarettes sold in Benin are presented in Table 1. The tested Beninese brands averaged 1.96 $\pm 1,01 \mu \mathrm{g} \mathrm{g}^{-1} \mathrm{~Pb}$ (range 1.15-3.85), 47.23 $\pm 21.64 \mu \mathrm{g} \mathrm{g}^{-1} \mathrm{Cd}$ (range 26.0384.79), 5.25 $\pm 0.24 \mu \mathrm{g} \mathrm{g}^{-1} \mathrm{Ni}$ (range 4.97-5.66.) and $37.14 \pm 42.96 \mu \mathrm{g} \mathrm{g}^{-1}$ As (range 1.01-95.25). According this table, there was no significant difference $(p<0.05)$ in cadmium concentrations of cigarette brands. The lowest concentration was recorded in Green Concorde brand whereas the highest in Yes brand. Similarly, no significant difference $(p<0.05)$ was observed in nickel concentrations among the 6 cigarette brands used in Benin. The lowest concentration was recorded in Graven brand whereas the highest in Yes brand. Concerning lead contents, there was no significant difference $(p<0.05)$ between Marlboro, Graven A and Yes. 
Lucien Agbandji et al. / American Journal of Pharmacology and Toxicology 7 (4) (2012) 149-153

Table 1. Concentration $(\mu \mathrm{g} / \mathrm{g})$ of heavy metals in imported cigarettes and cigarettes made and sold in Benin

\begin{tabular}{lllll}
\hline & $\mathrm{Cd}$ & $\mathrm{Pb}$ & $\mathrm{Ni}$ & $\mathrm{As}$ \\
\hline Marlboro & $2.34 \pm 0.76$ & $37.08 \pm 1.19$ & $5.18 \pm 0.98$ & $81.83 \pm 5.61^{* *}$ \\
Rothmans & $1.48 \pm 0.40$ & $55.53 \pm 1.44^{*}$ & $5.40 \pm 2.52$ & $1.01 \pm 1$ \\
Craven A & $1.31 \pm 1.11$ & $29.86 \pm 2.43$ & $4.97 \pm 0.73$ & $95.25 \pm 9.97^{* * *}$ \\
Red Concorde & $1.67 \pm 1.93$ & $50.13 \pm 4.14^{*}$ & $5.09 \pm 1.33$ & $1.77 \pm 6.53$ \\
Green Concorde & $1.15 \pm 1.13$ & $84.79 \pm 3.11^{* *}$ & $5.21 \pm 1.01$ & $1.38 \pm 3.46$ \\
Yes & $3.85 \pm 2.39$ & $26.03 \pm 2.36$ & $5.66 \pm 2.39$ & $41.60 \pm 9.18^{*}$ \\
Average \pm SD & $1,96 \pm 1,01$ & $47,23 \pm 21,64$ & $5,25 \pm 0,24$ & $37,14 \pm 42,96$ \\
\hline
\end{tabular}

The signe *; Represented the statistically significantly difference among mean values at $5 \%$ level of Probability in each column metal

Table 2. Concentration $(\mu \mathrm{g} / \mathrm{g})$ of heavy metals in cigarettes made and sold in France

\begin{tabular}{lllll}
\hline & $\mathrm{Cd}$ & $\mathrm{Pb}$ & $\mathrm{Ni}$ & $\mathrm{As}$ \\
\hline Marlboro & $4.33 \pm 1.43$ & $46.16 \pm 2.14^{*}$ & $4.70 \pm 1.76$ & $89.55 \pm 5.26^{*}$ \\
Rothmans & $4.54 \pm 1.52$ & $13.31 \pm 1.38$ & $5.65 \pm 0.50$ & $2 \pm 1.59$ \\
Craven A & $4.28 \pm 1.41$ & $63.51 \pm 2.63^{* *}$ & $4.11 \pm 1.13$ & $1.01 \pm 1$ \\
Average \pm SD & $4,38 \pm 0,11$ & $40,99 \pm 20,81$ & $4,82 \pm 0,63$ & $30,85 \pm 41,50$ \\
\hline
\end{tabular}

The signe *; represented the statistically significantly difference among mean values at $5 \%$ level of Probability in each column metal.

Table 3. Comparison of concentrations $(\mu \mathrm{g} / \mathrm{g})$ of heavy metals in cigarettes sold in Benin and France

\begin{tabular}{|c|c|c|c|c|c|c|c|c|}
\hline & \multicolumn{2}{|l|}{$\mathrm{Cd}$} & \multicolumn{2}{|l|}{$\mathrm{Pb}$} & \multicolumn{2}{|l|}{$\mathrm{Ni}$} & \multicolumn{2}{|l|}{ As } \\
\hline & Benin & France & Benin & France & Benin & France & Benin & France \\
\hline Marlboro & $2.34 \pm 0.76$ & $4.33 \pm 1.43$ & $37.08 \pm 1.19$ & $46.16 \pm 2.14$ & $5.18 \pm 0.98$ & $4.70 \pm 1.76$ & $81.83 \pm 5.61$ & $89.55 \pm 5.26$ \\
\hline Rothmans & $1.48 \pm 0.40$ & $4.54 \pm 1.52$ & $55.53 \pm 1.44^{*}$ & $13.31 \pm 1.38$ & $5.70 \pm 2.52$ & $5.65 \pm 0.50$ & $1.01 \pm 3.89$ & $2 \pm 1.59$ \\
\hline Craven A & $1.31 \pm 1.11$ & $4.28 \pm 1.41$ & $50.13 \pm 4.14$ & $63.51 \pm 2.63$ & $4.97 \pm 0.73$ & $4.11 \pm 1.13$ & $95.25 \pm 9.97 *$ & $1.01 \pm 1$ \\
\hline Aver. \pm SD & $1,77 \pm 0,55$ & $4,38 \pm 0,11$ & $40,82 \pm 13,23$ & $40,99 \pm 20,81$ & $5,18 \pm 0,21$ & $4,82 \pm 0,63$ & $59,36 \pm 50,97$ & $30,85 \pm 41,50$ \\
\hline
\end{tabular}

The signe *; Represented the statistically significantly difference among mean values at $5 \%$ level of Probability in each ligne cigarette brand for each metal

But there was significant difference $(p<0.05)$ in lead concentrations in Red Concorde and Rothmans brands brand compared to the other ones, excepted for Green Concorde brand which lead level was substantially higher $\left(84.79 \mu \mathrm{g} \mathrm{g}^{-1}\right)$. For arsenic contents, there was no significant difference $(\mathrm{p}<0.05)$ between Rothmans $(1.01$ $\left.\mu \mathrm{g} \mathrm{g}^{-1}\right)$, Green $\left(1.77 \mu \mathrm{g} \mathrm{g}^{-1}\right)$ and Red Concorde $(1.38 \mu \mathrm{g}$ $\left.\mathrm{g}^{-1}\right)$. On the other hand, there was significant difference $(p<0.05)$ between them and the other brands. But, by increasing order, the levels of as were substantially higher for yes $\left(41.60 \mu \mathrm{g} \mathrm{g}^{-1}\right)$, Marlboro $\left(81.83 \mu \mathrm{g} \mathrm{g}^{-1}\right)$ and Graven A $\left(95.25 \mu \mathrm{g} \mathrm{g}^{-1}\right)$. So, the highest arsenic concentration was recorded in Craven A brand while the lowest was recorded in Rothmans brand. What means that, the levels of As in Marlboro and Graven A were substantially higher (2-90 fold) compared to the other brands.

\subsection{Metals Concentration in France Cigarettes}

Average concentrations of lead, cadmium, nickel and arsenic in cigarettes made and sold in France is presented in Table 2. The tested France brands averaged $4.38 \pm 0,11 \mu \mathrm{g} \mathrm{g}^{-1} \mathrm{~Pb}$ (range 4.28-4.54), 40.99 $\pm 20,81 \mu \mathrm{g}$ $\mathrm{g}^{-1} \mathrm{Cd}$ (range 13.31-63.51), 4.82 $\pm 0,63 \mu \mathrm{g} \mathrm{g}^{-1} \mathrm{Ni}$ (range
4.11-5.65) and $30.85 \pm 41,50 \mu \mathrm{g} \mathrm{g}^{-1}$ As (range 1.0189.55). As depicted in this table, the levels of toxic metals varied considerably among brands. For cadmium and nickel concentrations, no significant differences $(p<0.05)$ were observed. Concerning lead contents, by increasing order, the levels were substantially higher $(\mathrm{p}<0.05)$ for Marlboro $\left(46.16 \mu \mathrm{g} \mathrm{g}^{-1}\right)$ and Graven A (63.51 $\mu \mathrm{g}^{-1}$ ) compared to Rothmans brand samples (13.31 $\mu \mathrm{g}$ $\left.\mathrm{g}^{-1}\right)$. For arsenic concentrations, there was no significant difference $(\mathrm{p}<0.05)$ between Rothmans and Graven A. But, the level of As in Marlboro was substantially $(p<0.05)$ higher (40-80 fold) compared to the other brands.

\subsection{Comparison of Beninese and France Cigarettes}

The comparison of heavy metals contents in cigarettes sold in Benin and France are presented in Table 3. Excepted the significantly differences $(p<0.05)$ recorded for $\mathrm{Pb}(55.53 \pm 1.44$ in Beninese Rothmans versus $13.31 \pm 1.38$ in France one) and for As $(95.25 \pm 9.97$ in Beninese Graven A versus $1.01 \pm 1$ in France one), there was no significant differences for 
heavy metals contents in cigarette brands sold in Benin and France. So, Rothmans cigarette brands of Benin contain about four times more lead that France Rothmans. Also, Graven A cigarette brands of Benin contain about ninety times more arsenic that Graven A sold in France. Otherwise, the average cadmium contents in France cigarettes brands is slightly higher than the average recorded in cigarettes smoked in Benin. Indeed, all the France cigarette brands contain about two or three times more cadmium that Beninese cigarettes. On the other hand, the average arsenic contents in Beninese cigarettes brands is slightly higher than the average recorded in cigarettes smoked in France. However, there was no significant difference $(p<0.05)$ between the averages metals contents for the three compared cigarette brands taken from the two countries. These results revealed that cadmium, lead, nickel and arsenic levels in Beninese cigarettes were comparable to those sold in France. The substantially differences between heavy metals contents were recorded essentially, not among the two countries, but from one cigarette brand to another one, inside each country. The results of this study are consistent with existing literature on presence of heavy metals in cigarettes (Watanabe et al., 1987; O'Connor et al., 2010). Metal content in tobacco leaf primarily is driven by the metal content of the soil in which it is grown, rather than resulting from processing (Golia et al., 2009). About the cadmium contents that are important in such studies, we did not find particularly high levels of cadmium in Benin like O'Connor et al. (2010) who recorded such results in Chine, developping country in cigarette tobacco. On the contrary, it was rather in all France cigarette brands that the cadmium levels were higher, which is probably the result of soil conditions where tobacco is grown in France. But, this debate is not important because the amounts reveal that, for all metals, the regulatory limits are over passed. Indeed, the presence of high levels of heavy metals may constitute a global health concern. Mussalo-Rauhamaa et al. (1986) found that $22-50 \%$ of the $\mathrm{Cd}$ was in the ash and stumps of the smoked cigarettes, which indicated that this element passed in large amounts to sidestream smoke. Recent work also suggests that cadmium and lead levels are higher in lung tissues of current and former smoking lung cancer patients relative to non-smokers (Palma et al., 2008). Did the tobacco industry have not the opportunity to test his crop in order to remove the most contaminated? Did such proposal can dent its huge profits? We thought, it's like gasoline with lead: heavy metals would be burn retardants. They would increase the amount of nicotine available when the cigarette consumme. This would be why they are still found in tobacco when they could not be there. Otherwise, smokers usually smoke 20 cigarettes or more per day and these heavy metals added a cocktail of tobacco toxic substances. While the relative health burden of metal exposure from tobacco is still unclear, Fowles and Dybing (2003) suggest that they might be at least as important in carcinogenesis as Polycyclic Aromatic Hydrocarbons (PAHs) and N-nitrosamines.

\section{CONCLUSION}

This study found that Beninese and France cigarettes contain potentially dangerous quantities of heavy metals (cadmium, lead, nickel and arsenic). Overall, these findings suggest that Beninese cigarettes did not differ in heavy metals contents from cigarettes sold in France markets, though they follow similar patterns in determining cadmium, lead, nickel and arsenic yields under standard testing conditions. But the presence of high levels of some heavy metals both in some Beninese and France cigarettes may constitute a potential global public health problem as manufactures and exports continue to increase. Regulators should require disclosure of the source and growing conditions of tobacco used in all products and should consider product standards based on heavy metal content.

\section{REFERENCES}

Anane, R., M. Bonini, M.J. Grafeille and E.E. Creppy, 1995. Bioaccumulation of water soluble aluminium chloride in the hippocampus after transdermal uptake in mice. Arch. Toxicol., 69: 568-571. DOI: 10.1007/s002040050214

Bourrelier, P.H. and J. Berthelin, 1998. Contamination des Sols par les Elements en Traces: Les Risques et Leur Gestion. Ist Edn., Tec and Doc, Lavoisier, Paris, ISBN-10: 2743002913, pp: 440.

Connolly, G.N., D.M. Winn, S.S. Hecht, D.J. Henningfiel and B.J. Walker et al., 1986. The reemergence of smokeless tobacco. N. Engl. J. Med., 314: 1020-1027. PMID: 3515184.

Deluisa, A., P. Giandon, M. Aichner, P. Bortolami and L. Bruna et al., 1996. Copper pollution in italian vineyard soils. Commun. Soil Sci. Plant Anal., 27: 1537-1548. DOI: 10.1080/00103629609369651

Fowles, J. and E. Dybing, 2003. Application of toxicological risk assessment principles to the chemical constituents of cigarette smoke. Tob Control, 12: 424-430. DOI: 10.1136/tc.12.4.424 
Friberg, L., 1974. Cadmium in the Environment. 2nd Edn., CRC Press Inc., Cleveland, ISBN: 10087819018X, pp: 248

Galanti, L., V. Godding, J.F. Questiaux and J. Evrard, 1997. Quantification of passive exposition to tobacco smoke of newborn babies, children and adults. J. Am. Coll. Cardiol. 29: 5412-5412.

Golia, E.E., A. Dimirkou and I.K. Mitsios, 2009. Heavymetal concentration in tobacco leaves in relation to their available soil fractions. Communi. Soil Sci. Plant Anal., 40: 106-20. DOI: 10.1080/00103620802623570

Kaplan, M., L. Carriker and I. Waldron, 1990. Gender difference in tobacco use in Kenya. Soc. Sci. Med. 30: 305-310. DOI: 10.1016/0277-9536(90)90186-V

Kjellstrom, T., 1979. Exposure and accumulation of cadmium in populations from Japan, the United States, and Sweden. Environ. Health Perspect., 28: 169-197.

Mussalo-Rauhamaa, H., S.S. Salmela, A. Leppänen and H. Pyysalo, 1986. Cigarettes as a source of some trace and heavy metals and pesticides in man. Int. J. Arch. Environ. Health, 41: 49-55. DOI: 10.1080/00039896.1986.9935765

O’Connor, R.J., L. Qiang, W.E. Stephens, D. Hammond and T. Elton-Marshall et al., 2010. Cigarettes sold in China: Design, emissions and metals. Tob Control, 19: i47-i53. DOI: 10.1136/tc.2009.030163

Palma, G.D., M. Goldoni, S. Catalani, P. Carbognani and D. Poli et al., 2008. Metallic elements in pulmonary biopsies from lung cancer and control subjects. Acta Biomed., 79: 43-51.

Peltzer, K., 2003. Smokeless tobacco and cigarette use among black secondary school students in South Africa. Subst. Use Misuse, 38: 1003-1016. PMID: 12801153
Pietel, J., K. Kuroiwa and H.T. Sawyerr, 2000. Distribution of $\mathrm{Pb}, \mathrm{Cd}$ and $\mathrm{Ba}$ in soils and plants of two contamined soils. Environ. Pollut., 110: 171178. DOI: 10.1016/S0269-7491(99)00272-9

Saad, Z., V. Kazpard, A. El Samrani, K. Slim and P. Nabhan, 2006. Relations entre métaux traces dans le tabac et la nature du sol au Liban. Cahiers Agricultures, 15: 203-211.

Sasco, A., M. Secretan and K. Straif, 2004. Tobacco smoking and cancer: A brief review of recent epidemiological evidence. Lung Cancer, 45: 3-9. DOI: 10.1016/j.lungcan.2004.07.998

Scherer, G. and H. Barkemeyer, 1983. Cadmium concentrations in tobacco and tobacco smoke. Ecotoxi. Environ. Safety, 7: 71-78. DOI: 10.1016/0147-6513(83)90050-7

Vaidya, C.O. and R.T.T. Rantala, 1996. A comparative study of analytical methods: Determination of heavy metals in mussels (Mytilus edulis) from Eastern Canada. Int. Environ. Anal. Chem., 63: 179-185. DOI: $10.1080 / 03067319608026264$

Watanabe, T., M. Kasahara, H. Nakatsuka and I. Masayuki, 1987. Cadmium and lead contents of cigarettes produced in various areas of the world. Sci. Total. Environ., 66: 29-37. DOI: 10.1016/00489697(87)90074-X

Xian, X., 1989. Effect of chemical forms of cadmium, zinc and lead in polluted soils on their uptake by cabbage plants. Plant Soil, 113: 257-264. DOI: 10.1007/BF02280189 